\title{
PENGARUH KEPRIBADIAN, LINGKUNGAN KELUARGA, DAN TEMAN SEBAYA TERHADAP MINAT BERWIRAUSAHA MAHASISWA PROGRAM STUDI PENDIDIKAN AKUNTANSI FAKULTAS EKONOMI UNIVERSITAS NEGERI YOGYAKARTA
}

\author{
THE EFFECT OF PERSONALITY, FAMILY ENVIRONMENT, AND PEER GROUP \\ TOWARD INTEREST IN ENTREPRENEURSHIP OF ACCOUNTING EDUCATION \\ STUDENTS AT FACULTY OF ECONOMICS YOGYAKARTA STATE UNIVERSITY
}

\author{
Oleh: \\ Siti Nafi'ah Nurhadifah \\ Pendidikan Akuntansi Universitas Negeri Yogyakarta \\ Snafiah2502@gmail.com \\ $\underline{\text { Sukanti }}$ \\ Staf Pengajar Jurusan Pendidikan Akuntansi Universitas Negeri Yogyakarta
}

\begin{abstract}
Abstrak
Penelitian ini bertujuan untuk mengetahui (1) Pengaruh Kepribadian terhadap Minat Berwirausaha mahasiswa program studi Pendidikan Akuntansi Fakultas Ekonomi Universitas Negeri Yogyakarta, (2) Pengaruh Lingkungan Keluarga terhadap Minat Berwirausaha mahasiswa program studi Pendidikan Akuntansi Fakultas Ekonomi Universitas Negeri Yogyakarta, (3) Pengaruh Teman Sebaya terhadap Minat Berwirausaha mahasiswa program studi Pendidikan Akuntansi Fakultas Ekonomi Universitas Negeri Yogyakarta, dan (4) Pengaruh Kepribadian, Lingkungan Keluarga, dan Teman Sebaya secara bersama-sama terhadap Minat Berwirausaha mahasiswa program studi Pendidikan Akuntansi Fakultas Ekonomi Universitas Negeri Yogyakarta.

Populasi dari penelitian ini adalah mahasiswa program studi Pendidikan Akuntansi Fakultas Ekonomi Universitas Negeri Yogyakarta yang telah menempuh mata kuliah kewirausahaan yaitu angkatan 2014 dan 2015 dengan jumlah 114 mahasiswa. Uji coba instrumen dilakukan di program studi Pendidikan Ekonomi FE UNY angkatan 2014 dan 2015 secara acak kepada 30 mahasiswa. Uji prasyarat analisis dalam penelitian ini adalah uji linieritas, uji multikolinieritas, dan uji heteroskedastisitas. Teknik analisis yang digunakan adalah teknik analisis regresi sederhana untuk hipotesis pertama, kedua, dan ketiga serta analisis regresi ganda untuk hipotesis keempat.

Berdasarkan hasil penelitian diperoleh kesimpulan: (1) terdapat pengaruh positif Kepribadian terhadap Minat Berwirausaha mahasiswa program studi Pendidikan Akuntansi Fakultas Ekonomi Universitas Negeri Yogyakarta dengan nilai $r_{x 1 y}$ sebesar 0,$755 ; r_{x 1 y}^{2}$ sebesar 0,$570 ;$ (2) terdapat pengaruh positif Lingkungan Keluarga terhadap Minat Berwirausaha mahasiswa program studi Pendidikan Akuntansi Fakultas Ekonomi Universitas Negeri Yogyakarta dengan nilai $\mathrm{r}_{\mathrm{x} 2 \mathrm{y}}$ sebesar 0,$515 ; r_{x 2 y}^{2}$ sebesar 0,$265 ;(3)$ terdapat pengaruh positif Teman Sebaya terhadap Minat Berwirausaha mahasiswa program studi Pendidikan Akuntansi Fakultas Ekonomi Universitas Negeri Yogyakarta dengan nilai $r_{x 3 y}$ sebesar 0,$453 ; r_{x 3 y}^{2}$ sebesar 0,205 ; (4) terdapat pengaruh Kepribadian, Lingkungan Keluarga, dan Teman Sebaya secara bersama-sama terhadap Minat Berwirausaha mahasiswa program studi Pendidikan Akuntansi Fakultas Ekonomi Universitas Negeri Yogyakarta dengan nilai $\mathbf{R}_{(1,2,3)}$ sebesar 0,$778 ; \mathrm{R}_{(1,2,3)}^{2}$ sebesar 0,605 .
\end{abstract}

Kata Kunci: Kepribadian, Lingkungan Keluarga, Teman Sebaya, dan Minat Berwirausaha. 


\section{Abstract}

This research aims to determine the effect of (1) Personality toward Interest in Entrepreneurship of Accounting Education Students at Faculty of Economics Yogyakarta State University, (2) Families Environment toward Interest in Entrepreneurship of Accounting Education Students at Faculty of Economics Yogyakarta State University, (3) Peer Group toward Interest in Entrepreneurship of Accounting Education Students at Faculty of Economics Yogyakarta State University, (4) Personality, Family Environment, and Peer Group toward Interest in Entrepreneurship of Accounting Education Students at Faculty of Economics Yogyakarta State University.

Population of this research were 114 students of Accounting Education at Faculty of Econimics Yogyakarta State University class of 2014 and 2015 who took Entrepreneurship course. The research instrument was tested to 30 students of Economics Education at Faculty of Economics Yogyakarta State University class of 2014 and 2015 randomly. The analysis prerequisite tests that used were linearity, multicollinearity, and heteroscedasticity test. The data analysis techniques that used are simple linear regression analysis for the first, second, and third hypothesis and multiple regression analysis for the fourth hypothesis.

Based on the research that has been done, it can be concluded that : (1) There is a positive effect of Personality toward Interest in Entrepreneurship of Accounting Education Students at Faculty of Economics Yogyakarta State University by $r_{x l y}=(0,755), r_{x y y}^{2}(0,570) ;(2)$ There is a positive effect of Family Environment toward Interest in Entrepreneurship of Accounting Education Students at Faculty of Economics Yogyakarta State University by $r_{x l y}(0,515), r_{x l y}^{2}(0265)$; (3) There is a positive effect of Peer Group toward Interest in Entrepreneurship of Accounting Education Students at Faculty of Economics Yogyakarta State University by $r_{x y y}(0,453), r_{x y y}^{2}(0,205) ;(4)$ There is a positive effect of Personality, Family Environment, and Peer Group toward Interest in Entrepreneurship of Accounting Education Students at Faculty of Economics Yogyakarta State University by $R_{(1,2,3)}=(0,778), R_{(1,2,3)}^{2}=$ $(0,605)$.

Keywords: Personality, Family Environment, Peer Group, and Interest in Entrepreneurship

\section{PENDAHULUAN}

Sumber daya alam dan sumber daya manusia merupakan satu-kesatuan yang saling memengaruhi dalam suatu negara. Indonesia merupakan salah satu negara yang kaya akan sumber daya alam. Selain sumber daya alam yang melimpah, Indonesia juga salah satu negara dengan penyumbang sumber daya manusia paling banyak di dunia. Berdasarkan data dari CIA World Factbook tahun 2017 Indonesia menduduki peringkat keempat setelah China, India, dan Amerika Serikat, dengan jumlah penduduk Indonesia sebanyak 260.580.739 jiwa.

Pertumbuhan penduduk Indonesia dari tahun ke tahun semakin meningkat, seperti yang dilansir dalam keluargaindonesia.id tanggal 10 Oktober 2017, Surya Chandra Surapaty (Kepala Badan Kependudukan dan Keluarga Berencana Nasional Pusat) menyampaikan bahwa tahun 2017, jumlah penduduk Indonesia diperkirakan menembus 265 juta jiwa, lebih besar ketimbang negara berkembang lain. Laju pertumbuhan penduduk (LPP) per tahun juga lebih tinggi dari harapan, 1,49 persen per tahun, dari perkiraan 1,45 persen per tahun. Besarnya jumlah penduduk akan memberikan manfaat bagi negara jika sumber daya manusia yang ada memiliki kualitas baik yang dapat memanfaatkan sumber daya alam yang melimpah dengan bijak, jika tidak maka yang terjadi hanya akan menimbulkan permasalahan yaitu masalah pengangguran.

Pengangguran merupakan salah satu masalah yang menjadi sorotan di Indonesia pada saat ini. Meningkatnya laju pertumbuhan penduduk dari tahun ke tahun yang tidak diimbangi dengan jumlah lapangan pekerjaan yang tersedia akan memicu bertambahnya angka pengangguran di Indonesia. Data dari CIA World Factbook dengan kategori Jumlah Penduduk yang 
Tidak Bekerja umur 15-24 tahun menyatakan bahwa Indonesia menempati urutan ke 53 dari 161 negara, hal ini menunjukkan bahwa jumlah penduduk Indonesia yang meningkat juga diikuti dengan tingkat pengangguran yang semakin bertambah. Berikut jumlah tingkat pengangguran terbuka dari tahun ke tahun menurut data dari Badan Pusat Statistika:

Tabel 1. Tingkat Pengangguran Terbuka

\begin{tabular}{|c|c|c|c|c|}
\hline \multirow{2}{*}{$\begin{array}{c}\text { Jenis } \\
\text { Kegiatan }\end{array}$} & \multicolumn{2}{|c|}{2016} & \multicolumn{2}{|c|}{2017} \\
\hline & Feb & Agst & Feb & Agst \\
\hline $\begin{array}{l}\text { Penduduk } \\
\text { berumur } 15 \\
\text { tahun ke } \\
\text { atas }\end{array}$ & $\begin{array}{l}187 . \\
600 . \\
634\end{array}$ & $\begin{array}{l}189 . \\
096 . \\
722\end{array}$ & $\begin{array}{l}190 . \\
587 . \\
918\end{array}$ & $\begin{array}{l}192 . \\
079 . \\
416\end{array}$ \\
\hline $\begin{array}{l}\text { Angkatan } \\
\text { Kerja yang } \\
\text { bekerja }\end{array}$ & $\begin{array}{l}120 . \\
647 . \\
697\end{array}$ & $\begin{array}{l}118 . \\
411 . \\
973\end{array}$ & $\begin{array}{l}124 . \\
538 . \\
849\end{array}$ & $\begin{array}{l}121 . \\
022 . \\
423\end{array}$ \\
\hline $\begin{array}{l}\text { Angkatan } \\
\text { Kerja } \\
\text { Penganggur } \\
\text { an Terbuka }\end{array}$ & $\begin{array}{c}7.02 \\
4.17 \\
2\end{array}$ & $\begin{array}{c}7.03 \\
1.77 \\
5\end{array}$ & $\begin{array}{c}7.00 \\
5.26 \\
2\end{array}$ & $\begin{array}{c}- \\
7.04 \\
0.32 \\
3\end{array}$ \\
\hline
\end{tabular}

Sumber: www.bps.go.id

Dari tabel 1 tersebut dapat dilihat bahwa tingkat pengangguran terbuka mengalami peningkatan per februari 2017 hingga agustus 2017 sebanyak 35.061 jiwa. Hal ini akan berdampak buruk dalam suatu negara jika masalah pengangguran tidak diatasi dengan serius. Salah satu cara mengurangi pengangguran adalah dengan meningkatkan kuantitas wirausaha yang berperan dalam menciptakan lapangan pekerjaan. Wirausaha (entrepreneur) merupakan orang yang berjiwa berani mengambil risiko untuk membuka usaha dalam berbagai kesempatan. Berjiwa berani mengambil resiko artinya bermental mandiri dan berani memulai usaha, tanpa diliputi rasa takut atau cemas sekalipun dalam kondisi tidak pasti (Kasmir, 2011: 19).

Wirausaha merupakan hal yang penting bagi setiap negara. Serian Wijatno (2009: 9) mengungkapkan salah satu dampak terpenting dari entrepreneurship (kewirausahaan) adalah penyediaan lapangan pekerjaan, selain diri wirausaha sendiri yang tidak menambah angka pengangguran karena entrepreneur menciptakan pekerjaan dan bukan mencari kerja, entrepreneur mampu menciptakan pekerjaan untuk beberapa tenaga kerja hingga ribuan tenaga kerja. Pentingnya kewirausahaan bagi suatu negara juga dapat dilihat dari negara-negara yang telah berhasil maju dan juga berhasil dalam meningkatkan kemakmuran rakyatnya seperti Jepang, Korea Selatan, Taiwan, Singapura, Amerika Serikat, Kanada, negara-negara Eropa Barat, Australia, Inggris, dan lain sebagainya disebabkan oleh salah satu utamanya karena negara-negara tersebut memiliki banyak wirausaha.

Pendapat tersebut diperkuat dengan penelitian Heflin Frinces yang menyatakan besarnya peran yang dimainkan oleh wirausaha di dalam mengatasi berbagai problematik pembangunan ekonomi nasional seperti masalah pengentasan kemiskinan, tingginya jumlah pengangguran, rendahnya daya beli, sulitnya penciptaan lapangan usaha dan lapangan kerja, serta peningkatan pertumbuhan ekonomi. Seperti yang diungkapkan Buchari Alma (2013: 1) Semakin maju suatu negara semakin banyak orang yang terdidik, dan semakin banyak orang menganggur maka semakin penting dunia wirausaha. Pembangunan suatu negara jauh lebih berhasil jika dengan ditunjang banyaknya wirausahawan yang dapat membuka lapangan kerja, hal ini dikarenakan kemampuan pemerintah sangat terbatas, oleh karena itu wirausaha menjadi potensi pembangunan.

Dilansir dari bisnis.liputan6.com pada 15 Januari 2018, Menteri Koperasi dan UKM yaitu Anak Agung Gede Ngurah Puspayoga menjelaskan bahwa rasio wirausaha di Indonesia sudah meningkat menjadi 3,1 persen dari total penduduk Indonesia dari sebelumnya hanya 1,55 persen di 2014. Jika dihitung dengan jumlah penduduk Indonesia sekitar 260 juta jiwa, 
maka jumlah wirausaha Indonesia saat ini mencapai sekitar 8,06 juta jiwa. Dengan demikian tingkat kewirausahaan Indonesia telah melampaui 2 persen dari populasi penduduk, sebagai syarat minimal suatu masyarakat akan sejahtera. Meskipun ratio wirausaha naik menjadi 3,1 persen jumlah tersebut masih lebih rendah dibandingkan dengan negara lain seperti Malaysia 5 persen, China 10 persen, Singapura 7 persen, Jepang 11 persen dan AS 12 persen. Untuk mengejar ketertinggalam dalam menumbuhkan wirausaha dari negaranegara tersebut, perlu adanya peran dan partisipasi dari masyarakat bersama pemerintah, swasta, mahasiswa, maupun perguruan tinggi untuk menanamkan jiwa kewirausahaan.

Jiwa kewirausahaan perlu ditumbuhkan untuk mengatasi masalah pengangguran. Langkah awal untuk menumbuhkan jiwa kewirausahaan adalah dengan menanamkan minat berwirausaha khususnya pada mahasiswa. Minat Berwirausaha merupakan perasaan senang dan tertarik terhadap peluang bisnis yang ada dan memerlukan keberanian dalam mengambil risiko serta kreativitas untuk memperoleh keuntungan. Mahasiswa sebagai salah satu calon penerus bangsa penting untuk memiliki jiwa kewirausahaan, karena setelah lulus dari perguruan tinggi akan dihadapkan pada dua pilihan yaitu mencari kerja atau menciptakan lapangan pekerjaan.

Data bps tentang tingkat pengangguran terbuka menurut pendidikan tertinggi yang ditamatkan pada jenjang Universitas mengalami peningkatan dari Agustus 2016 sebanyak 567.235 jiwa menjadi Agustus 2017 sebanyak 618.758 jiwa. Hal ini mengindikasikan bahwa lulusan perguruan tinggi ikut menyumbang bertambahnya pengangguran di Indonesia. Oleh karena itu peran dari perguruan tinggi sangat diperlukan untuk dapat mengarahkan lulusannya agar mandiri dengan menciptakan lapangan pekerjaan sendiri tidak bergantung pada lapangan pekerjaan yang minim.

Dilansir dari netralnews.com Menteri Puspayoga mengemukakan bahwa mindset mahasiswa masih berlomba menjadi pegawai negeri atau karyawan, sedangkan pola pikir untuk menjadi wirausaha sangat minim. Mindset seperti itu perlu diubah, dari mindset pegawai menjadi pengusaha. Beliau juga menegaskan bahwa dukungan perguruan tinggi sangat dibutuhkan untuk menumbuhkan minat berwirausaha di kalangan mahasiswa, karena tumbuhnya wirausaha baru dari kalangan mahasiswa akan meningkatkan rasio kewirausahaan nasional.

Apalagi kondisi saat ini persaingan global semakin meningkat dengan adanya MEA (Masyarakat Ekonomi Asean) dimana masyarakat Indonesia tidak terkecuali lulusan perguruan tinggi semakin terdesak dan tergeser oleh tenaga asing yang bekerja di Indonesia. Dampak dari hal ini mengharuskan perguruan tinggi mampu membimbing dan mendorong mahasiswanya untuk dapat menjadi pencipta lapangan pekerjaan (wirausaha), bukan hanya sebatas menjadi pencari kerja. Dengan adanya jiwa kewirausahaan pada mahasiswa khususnya diharapkan akan tumbuh sikap dan kemauan untuk mandiri demi mendapatkan kehidupan yang sejahtera tanpa harus bergantung pada orang lain.

Universitas Negeri Yogyakarta (UNY) merupakan perguruan tinggi yang memiliki fasilitas pendukung kewirausahaan untuk mewadai minat dan bakat mahasiswa untuk berwirausaha seperti laboratorium kewirausahaan UNY, program-program kewirausahaan, kompetisi bisnis dan lainlain. Terlebih di Program Studi Pendidikan Akuntansi Fakultas Ekonomi juga memiliki fasilitas kewirausahaan yang dikelola oleh Himpunan Mahasiswa Pendidikan Akuntansi selain itu sering adanya seminar kewirausahaan. Berdasarkan hasil observasi yang dilakukan pada bulai Mei 2017 menunjukkan bahwa fasilitas yang telah disediakan belum dimanfaatkan dengan 
optimal oleh para mahasiswa, hal ini mengindikasikan kurangnya minat berwirausaha pada mahasiswa Program Studi Pendidikan Akuntansi.

Hasil pra survei yang dilakukan peneliti pada tanggal 22 Mei 2017 pada mahasiswa Program Studi Pendidikan Akuntansi menunjukkan bahwa $81 \%$ mahasiswa kurang berminat wirausaha karena mereka lebih menginginkan menjadi pegawai baik pegawai negeri maupun PNS, diperkuat dengan hasil wawancara yang telah dilakukan menyebutkan bahwa kurangnya minat dalam dunia wirausaha mahasiswa dikarenakan mereka merasa menjadi seorang wirausaha tidaklah mudah, perlu sikap pemberani dan tidak mudah menyerah untuk menghadapi segala resiko yang akan terjadi, mereka menganggap menjadi pegawai memiliki pekerjaan yang lebih mudah dengan tingkat resiko yang sedikit. Meskipun ada beberapa yang menginginkan menjadi wirausaha, akan tetapi hal itu hanya menjadi sebatas keinginan mahasiswa tanpa ada tindak lanjut yang dilakukan.

Padahal di Indonesia terdapat banyak pelamar CPNS setiap tahunnya, bahkan antara formasi dengan jumlah pelamar perbandingan rasionya sangat jauh. Seperti yang diilansir dari m.liputan6.com pada tanggal 10 Oktober 2017, Zulfi Suhendra mengatakan bahwa terdapat 17.928 posisi CPNS di 61 instansi dengan jumlah pelamar tercatat sebanyak 657.841. Hal ini membuktikan peluang menjadi PNS semakin kecil, artinya sektor pemerintah terbatas dalam menyerap lulusan perguruan tinggi. Oleh karena itu, peluang paling besar adalah dengan terjun dalam usaha mandiri (berwirausaha). Berwirausaha berpeluang menghasilkan pendapatan yang lebih besar daripada menjadi karyawan, serta berwirausaha akan menyerap tenaga kerja artinya membantu pemerintah mengatasi pengangguran dan berkontribusi meningkatkan perekonomian melalui pajak yang dihasilkan.
Minat Berwirausaha menurut Daryanto (2013: 15) dipengaruhi oleh beberapa faktor yaitu 1) meyangkut aspek kepribadian seseorang, 2) hubungan dengan temanteman, 3) hubungan dengan orang tua dan famili, serta 4) hubungan seseorang dengan lingkungannya. Sedangkan menurut Bygrave (dalam Buchari Alma, 2013: 9) Minat Berwirausaha dipengaruhi beberapa faktor yaitu 1) faktor personal, yang menyangkut aspek kepribadian. 2) faktor environtment, yang menyangkut lingkungan fisik. 3) faktor sosiological, yang menyangkut hubungan dengan keluarga dan sebagainya.

Menjadi seorang wirausaha memerlukan kepribadian yang pemberani dan produktif. Menurut Gordon W. Allport (dalam Sarlito Sarwono, 2012: 171) kepribadian adalah organisasi dinamis dalam diri individu yang terdiri dari sistemsistem psiko-fisik yang menentukan cara penyesuaian diri yang unik (khusus) dari individu tersebut terhadap lingkungannya. Kepribadian seseorang yang memiliki minat berwirausaha dalam dirinya tertanam jiwa percaya diri, berani mengambil resiko, berjiwa kepemimpinan, inisiatif dan inovatif. Kepribadian tersebut perlu dimiliki oleh seorang wirausaha karena dalam menjalankan bisnis tentu perlu keberanian dalam setiap langkahnya, akan dibawa kemana usahanya, bagaimana menangani permasalahan usaha yang dihadapi, bagaimana mengkoordinir karyawan agar usaha tetap berkembang, dan lain-lain.

Berdasarkan hasil pra survei yang dilakukan peneliti pada tanggal 22 Mei 2017 pada mahasiswa Program Studi Pendidikan Akuntansi memberikan hasil bahwa $84 \%$ mahasiswa kurang berminat dalam dunia wirausaha karena mereka kurang berani mengambil resiko yang ada, seperti cara mendapatkan modal awal, kecemasan kebangkrutan dan kerugian, bingung akan usaha apa dan bagaimana memulainya, serta alasan lain-lain yang mengindikasikan belum terdapat jiwa kewirausahaan dalam kepribadian mahasiswa. Diperkuat dengan 
hasil wawancara yang telah dilakukan tentang pengaruh kepribadian terhadap minat berwirausaha mahasiswa Program Studi Pendidikan Akuntansi yang menerangkan bahwa para mahasiswa masih belum percaya pada kemampuan diri mereka sendiri untuk dapat menjalankan suatu usaha. Karena kepribadian mahasiswa yang kurang memiliki jiwa wirausaha sehingga belum dapat memanfaatkan fasilitas kewirausahaan yang ada dengan sebaik mungkin.

Hasil dari penelitian terdahulu yang dilakukan Clement K. Wang menyatakan bahwa latar belakang keluarga memengaruhi minat berwirausaha. Hasbullah (2005: 38) mengungkapkan lingkungan keluarga merupakan lingkungan pendidikan bagi anak yang pertama karena di dalam keluarga inilah anak pertama kalinya mendapatkan pendidikan dan bimbingan dari orang tua yang akan memengaruhi dalam kelanjutan kehidupannya, termasuk pada pemilihan karir. Tidak sedikit seseorang yang menentukan karir akan meminta pendapat pada keluarga. Semakin orang tua memberikan dukungan positif seperti memberikan kebebasan, memberi bantuan dan perlakuan yang mendukung minat anaknya maka semakin terdorong pula minat anak dalam dunia wirausaha, begitu pula sebaliknya.

Tak jarang latar belakang orang tua juga memengaruhi minat anak. Orang tua dengan latar belakang wirausaha cenderung akan memberikan pengetahuan dan pengalaman yang telah didapatkan orang tua untuk mengarahkan anaknya memasuki dunia wirausaha. Berdasarkan hasil pra survei dan wawancara yang dilakukan peneliti pada tanggal 22 Mei 2017 pada mahasiswa Program Studi Pendidikan Akuntansi memberikan hasil bahwa 78,6\% mahasiswa yang lebih menginginkan menjadi PNS juga karena dorongan dari orang tua, keluarga mereka menginginkan mereka hidup dengan jaminan gaji yang tetap dan mendapat tunjangan ketika sudah pensiun kelak.
Teman sebaya merupakan keluarga ke dua setelah orang tua dan kakak adik. Bahkan tak jarang teman sebaya lebih mengetahui banyak dibandingkan dengan keluarga. Teman sebaya adalah kelompok remaja yang memiliki minat, nilai-nilai, dan pendapat yang sepemikiran, serta salah satu fungsinya sebagai sumber informasi dan tukar pikiran. Sekelompok teman sebaya yang mayoritas memiliki kesukaan dan minat yang sama dalam dunia wirausaha maka teman sekelompok juga akan terpengaruhi menyukai dunia wirausaha, hal ini dikarenakan mereka memiliki pemikiran dan kegiatan yang sama.

Berdasarkan hasil pra survei dan wawancara yang dilakukan peneliti pada tanggal 22 Mei 2017 pada mahasiswa Program Studi Pendidikan Akuntansi memberikan hasil bahwa $76 \%$ mahasiswa cenderung akan mengikuti teman atau kelompok mereka jika saling memiliki kesamaan pemikiran. Fakultas Ekonomi sering mengadakan seminar kewirausahaan akan tetapi tidak banyak yang mengikuti kegiatan tersebut dikarenakan kelompok teman sebaya mereka tidak mau mengikutinya, lebih memilih berkumpul untuk sekedar berbincang-bincang dan bersendau gurau dengan teman sebaya yang lain.

Faktor-faktor seperti kepribadian, lingkungan keluarga, dan teman sebaya merupakan faktor-faktor yang penting dalam menumbuhkan minat berwirausaha seseorang. Berdasarkan latar belakang tersebut, maka peneliti ingin mengetahui apakah Kepribadian, Lingkungan Keluarga, dan Teman Sebaya memengaruhi Minat Berwirausaha Mahasiswa Pendidikan Akuntansi. Peneliti tertarik untuk melakukan penelitian dengan judul "Pengaruh Kepribadian, Lingkungan Keluarga, dan Teman Sebaya terhadap Minat Berwirausaha Mahasiswa Pogram Studi Pendidikan Akuntansi Fakultas Ekonomi Universitas Negeri Yogyakarta”. 


\section{METODE PENELITIAN}

\section{Jenis Penelitian}

Jenis penelitian ini merupakan penelitian $e x$ post facto. Pendekatan yang digunakan dalam penelitian ini adalah pendekatan kuantitatif, karena data penelitian berupa angka-angka dan analisisnya menggunakan statistik.

\section{Waktu dan Tempat Penelitian}

Penelitian ini dilaksanakan di Fakultas Ekonomi Universitas Negeri Yogyakarta yang beralamat di Karangmalang, Catur Tunggal, Depok, Sleman, Yogyakarta. Penelitian ini dilaksanakan pada Program Studi Pendidikan Akuntansi pada bulan Januari sampai Februari 2018.

\section{Variabel Penelitian}

a. Variabel terikat (Variabel Dependen) dalam penelitian ini yaitu Minat Berwirausaha (Y)

b. Variabel bebas (Variabel Independen) dalam penelitian ini yaitu Kepribadian $\left(\mathrm{X}_{1}\right)$, Lingkungan Keluarga $\left(\mathrm{X}_{2}\right)$, dan Teman Sebaya $\left(\mathrm{X}_{3}\right)$

\section{Populasi Penelitian}

Populasi dalam penelitian ini adalah seluruh mahasiswa Program Studi Pendidikan Akuntansi Fakultas Ekonomi Universitas Negeri Yogyakarta yang telah mengambil mata kuliah kewirausahaan Tahun Ajaran 2016/017, yang terdiri dari angkatan 2014 sebanyak 94 mahasiswa dan angkatan 2015 sebanyak 20 mahasiswa, sehingga total populasi penelitian ini berjumlah 114 mahasiswa. Penelitian ini merupakan penelitian populasi karena menggunakan seluruh populasi yang ada.

\section{Data, Instrumen dan Teknik Pengumpulan Data}

a) Data

Data yang diperoleh adalah data kuantitatif. Teknik pengumpulan data yang digunakan, yaitu angket. Angket yang digunakan dalam penelitian ini adalah angket tertutup yang sudah disediakan jawabannya sehingga responden tinggal memilih alternatif jawaban yaitu Selalu (SL)/Sangat Setuju (SS), Sering (SR)/Setuju (S), Jarang (JR)/Tidak Setuju (TS), Tidak Pernah (TP)/ Sangat Tidak Setuju (STS).

b) Teknik Analisis Data

Teknik analisis data yang digunakan dalam penelitian ini adalah statistik deskriptif. Data kuantitatif yang diperoleh dari koesioner dianalisis secara kuantitatif dalam bentuk persentase. Analisis data meliputi meliputi penyajian Mean (M), Median (Me), Modus (Mo), Standar Deviasi (SD), tabel distribusi frekuensi, grafik, dan tabel kategori kecenderungan masing-masing variabel dengaan kategori tinggi/baik, sedang/cukup baik dan rendah/kurang baik. Tabel kecenderungan variabel dikategorikan dengan aturan sebagai berikut :

Tabel 2. Data Pengelompokkan Kecenderungan Skor

\begin{tabular}{|c|c|}
\hline Rentang & Kategori \\
\hline $\mathrm{X}>(\mathrm{Mi}+1 \mathrm{SDi})$ s.d. $(\mathrm{Mi}+3$ & $\begin{array}{c}\text { Tinggi/ } \\
\text { Baik }\end{array}$ \\
\hline $\mathrm{X}>(\mathrm{Mi}+$ 1SDi) s.d. $(\mathrm{Mi}+3$ & $\begin{array}{c}\text { Sedang/ } \\
\text { Cukup } \\
\text { SDi })\end{array}$ \\
$\begin{array}{c}\text { Baik } \\
\mathrm{X}>(\mathrm{Mi}+1 \mathrm{SDi}) \text { s.d. }(\mathrm{Mi}+3 \\
\text { SDi })\end{array}$ & $\begin{array}{c}\text { Kendah/ } \\
\text { Burang } \\
\end{array}$ \\
\hline
\end{tabular}

(Wagiran, 2013: 337)

Setelah itu akan dianalisis dengan analisis regresi sederhana dan regresi ganda serta dihitung sumbangan relatif dan sumbangan efektifnya, dan data harus lulus uji prasyarat analisis terlebih dahulu yang terdiri dari uji linearitas, uji multikolinearitas, dan uji heteroskedastititas.

\section{HASIL PENELITIAN DAN PEMBAHASAN}

1. Data variabel Minat Berwirausaha diperoleh melalui angket yang diberikan 
kepada 114 mahasiswa program studi Pendidikan Akuntansi angkatan 2014 dan 2015 yang telah menempuh mata kuliah kewirausahaan. Angket tersebut terdiri dari 13 butir pernyataan. Data kemudian diolah sehingga menghasilkan skor tertinggi yaitu 51 dari 52, sedangkan skor terendahnya adalah 22 dari 13. Selain itu diketahui nilai Mean sebesar 37,11; Median sebesar 37; Modus sebesar 39; serta Standar deviasi sebesar 5,72.

Tabel 3. Distribusi Frekuensi Skor Variabel Minat Berwirausaha

\begin{tabular}{|c|c|c|c|}
\hline No & $\begin{array}{c}\text { Kelas } \\
\text { Interval }\end{array}$ & Frekuensi & Persentase \\
\hline 1 & $22-25$ & 2 & $1,75 \%$ \\
\hline 2 & $26-29$ & 7 & $6,14 \%$ \\
\hline 3 & $30-33$ & 21 & $18,42 \%$ \\
\hline 4 & $34-37$ & 32 & $28,07 \%$ \\
\hline 5 & $38-41$ & 29 & $25,44 \%$ \\
\hline 6 & $42-45$ & 15 & $13,16 \%$ \\
\hline 7 & $46-49$ & 6 & $5,27 \%$ \\
\hline 8 & $50-53$ & 2 & $1,75 \%$ \\
\hline & Jumlah & 114 & $100 \%$ \\
\hline
\end{tabular}

Berdasarkan tabel di atas dapat disimpulkan bahwa mayoritas skor jawaban responden terdapat pada kelas interval 34-37 sebanyak 32 responden $(28,07 \%)$, sedangkan frekuensi terkecil terdapat pada kelas interval 22-25 dan 50-53 yang masing-masing berjumlah 2 responden $(1,75 \%)$.

Tabel 4. Distribusi Kecenderungan Variabel Minat Berwirausaha

\begin{tabular}{|c|c|c|c|}
\hline Kategori & $\begin{array}{c}\text { Interval } \\
\text { Skor }\end{array}$ & $\mathbf{F}$ & Persentase \\
\hline Baik & $\begin{array}{c}>39 \text { s.d } \\
52\end{array}$ & 45 & $39,47 \%$ \\
\hline Cukup & $\begin{array}{c}>26 \text { s.d. } \\
39\end{array}$ & 66 & $57,90 \%$ \\
\hline Kurang & $\begin{array}{c}13 \text { s.d. } \\
26\end{array}$ & 3 & $2,63 \%$ \\
\hline \multicolumn{2}{|c|}{ Jumlah } & 114 & $100 \%$ \\
\hline
\end{tabular}

Tabel di atas menunjukkan bahwa terdapat 45 responden $(39,47 \%)$ yang memiliki Minat Berwirausaha dengan kategori baik, sebanyak 66 responden $(57,90 \%)$ memiliki Minat Berwirausaha dalam kategori cukup, dan 3 responden $(2,63 \%)$ memiliki Minat Berwirausaha dengan kategori kurang. Dari hasil itulah dapat ditarik kesimpulan bahwa penilaian responden terhadap variabel Minat Berwirausaha adalah cukup.

\section{Minat Berwirausaha}

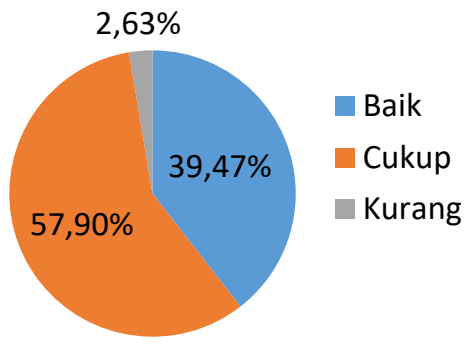

2. Data variabel Kepribadian diperoleh melalui angket yang diberikan kepada 114 mahasiswa program studi Pendidikan Akuntansi angkatan 2014 dan 2015 yang telah menempuh mata kuliah kewirausahaan. Angket tersebut terdiri dari 16 butir pernyataan. Data tersebut kemudian diolah sehingga menghasilkan skor tertinggi sebesar 62 dari 64, sedangkan skor terendahnya adalah 26 dari 16. Selain itu diketahui nilai Mean sebesar 43,40; Median sebesar 43; Modus sebesar 44; serta Standar deviasi sebesar 7,26.

Tabel 5. Distribusi Frekuensi Skor Variabel Kepribadian

\begin{tabular}{|l|c|c|c|}
\hline No & $\begin{array}{l}\text { Kelas } \\
\text { Interval }\end{array}$ & Frekuensi & Persentase \\
\hline 1 & $26-30$ & 5 & $4,38 \%$ \\
\hline 2 & $31-35$ & 8 & $7,02 \%$ \\
\hline 3 & $36-40$ & 22 & $19,30 \%$ \\
\hline 4 & $41-45$ & 40 & $35,09 \%$ \\
\hline
\end{tabular}




\begin{tabular}{|l|c|c|c|}
\hline No & $\begin{array}{l}\text { Kelas } \\
\text { Interval }\end{array}$ & Frekuensi & Persentase \\
\hline 5 & $46-50$ & 22 & $19,30 \%$ \\
\hline 6 & $51-55$ & 11 & $9,65 \%$ \\
\hline 7 & $56-60$ & 4 & $3,51 \%$ \\
\hline 8 & $61-65$ & 2 & $1,75 \%$ \\
\hline & Jumlah & 114 & $100 \%$ \\
\hline
\end{tabular}

Berdasarkan tabel di atas dapat disimpulkan bahwa mayoritas skor jawaban responden terdapat pada kelas interval 41-45 sebanyak 40 responden $(35,09 \%)$, sedangkan frekuensi terkecil terdapat pada kelas interval 61-65 yang berjumlah 2 responden $(1,75 \%)$.

Tabel 6. Distribusi Kecenderungan Variabel Kepribadian

\begin{tabular}{|l|l|l|l|}
\hline Kategori & $\begin{array}{l}\text { Interval } \\
\text { Skor }\end{array}$ & F & Persentase \\
\hline Produktif & $\begin{array}{l}>48 \text { s.d } \\
64\end{array}$ & 26 & $22,81 \%$ \\
\hline $\begin{array}{l}\text { Cukup } \\
\text { Produktif }\end{array}$ & $\begin{array}{l}>32 \text { s.d. } \\
48\end{array}$ & 79 & $69,30 \%$ \\
\hline $\begin{array}{l}\text { Kurang } \\
\text { Produktif }\end{array}$ & 16 s.d. 32 & 9 & $7,89 \%$ \\
\hline Jumlah & 114 & $100 \%$ \\
\hline
\end{tabular}

Tabel di atas menunjukkan sebanyak 26 responden $\quad(22,81 \%) \quad$ memiliki kepribadian dalam kategori produktif, sebanyak 79 responden $(69,30 \%)$ memiliki kepribadian dalam kategori cukup produktif, dan 9 responden $(7,89 \%)$ dengan kepribadian kategori kurang produktif. Penggolongan kategori dikatakan produktif, cukup produktif, dan kurang produktif didasarkan pada indikator variabel kepribadian yang digunakan. Mahasiswa yang memiliki kepribadian semakin produktif mencakup percaya diri, berani mengambil resiko, berjiwa kepemimpinan, inisiatif dan inovatif maka memiliki minat berwirausaha yang semakin baik pula, begitu juga sebaliknya. Dari hasil itulah dapat ditarik kesimpulan bahwa penilaian responden terhadap variabel Kepribadian adalah cukup produktif.

\section{Kepribadian}

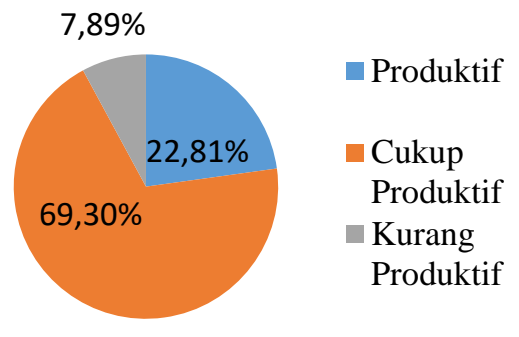

3. Data variabel Lingkungan Keluarga diperoleh melalui angket yang diberikan kepada 114 mahasiswa program studi Pendidikan Akuntansi angkatan 2014 dan 2015 yang telah menempuh mata kuliah kewirausahaan. Angket tersebut terdiri dari 9 butir pernyataan. Data tersebut kemudian diolah sehingga menghasilkan skor tertinggi sebesar 36 dari 36, sedangkan skor terendahnya adalah 14 dari 9. Selain itu diketahui nilai Mean sebesar 27,72; Median sebesar 28; Modus sebesar 29; serta Standar deviasi sebesar 4,24.

Tabel 7. Distribusi Frekuensi Skor Variabel Lingkungan Keluarga

\begin{tabular}{|c|c|c|c|}
\hline No & $\begin{array}{c}\text { Kelas } \\
\text { Interval }\end{array}$ & Frekuensi & Persentase \\
\hline 1 & $14-16$ & 1 & $0,88 \%$ \\
\hline 2 & $17-19$ & 0 & $0 \%$ \\
\hline 3 & $20-22$ & 14 & $12,28 \%$ \\
\hline 4 & $23-25$ & 21 & $18,42 \%$ \\
\hline 5 & $26-28$ & 22 & $19,30 \%$ \\
\hline 6 & $29-31$ & 40 & $35,09 \%$ \\
\hline 7 & $32-34$ & 7 & $6,14 \%$ \\
\hline 8 & $35-37$ & 9 & $7,89 \%$ \\
\hline & Jumlah & 114 & $100 \%$ \\
\hline
\end{tabular}

Berdasarkan tabel di atas dapat disimpulkan bahwa mayoritas skor jawaban responden terdapat pada kelas interval 29-31 sebanyak 40 responden 
$(35,09 \%)$, sedangkan frekuensi terkecil terdapat pada kelas interval 17-19 yang berjumlah 0 responden atau tidak ada sama sekali.

Tabel 8. Distribusi Kecenderungan Variabel Lingkungan Keluarga

\begin{tabular}{|l|l|l|l|}
\hline Kategori & $\begin{array}{l}\text { Interval } \\
\text { Skor }\end{array}$ & F & Persentase \\
\hline Mendukung & $\begin{array}{l}>27 \text { s.d } \\
36\end{array}$ & 65 & $57,02 \%$ \\
\hline $\begin{array}{l}\text { Cukup } \\
\text { Mendukung }\end{array}$ & $\begin{array}{l}>18 \\
\text { s.d. } 27\end{array}$ & 48 & $42,10 \%$ \\
\hline $\begin{array}{l}\text { Kurang } \\
\text { Mendukung }\end{array}$ & 9 s.d. 18 & 1 & $0,88 \%$ \\
\hline Jumlah & 114 & $100 \%$ \\
\hline
\end{tabular}

Tabel di atas menunjukkan bahwa terdapat 65 responden $(57,02 \%)$ yang memiliki lingkungan keluarga yang mendukung, sebanyak 48 responden $(42,10 \%)$ memiliki lingkungan keluarga dengan kategori cukup mendukung, dan 1 responden $(0,88 \%)$ dengan lingkungan keluarga kurang mendukung. Penggolongan kategori dikatakan mendukung, cukup mendukung, dan kurang mendukung didasarkan pada indikator variabel Lingkungan Keluarga yang digunakan. Semakin mahasiswa memiliki lingkungan keluarga yang mendukung yaitu mencakup keberfungsian keluarga, sikap dan perlakuan orang tua terhadap anak, serta status ekonomi maka lingkungan keluarga mahasiswa semakin meningkatkan minat berwirausaha, begitu juga sebaliknya. Dari hasil itulah dapat ditarik kesimpulan bahwa penilaian responden terhadap variabel Lingkungan Keluarga adalah mendukung.

\section{Lingkungan Keluarga}

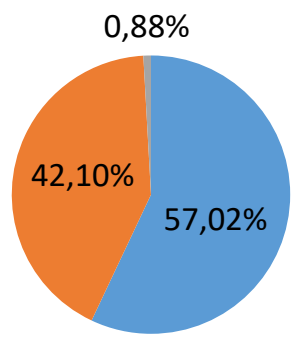

- Mendukung

- Cukup

Mendukung

Kurang

Mendukung

4. Data variabel Teman Sebaya diperoleh melalui angket yang diberikan kepada 114 mahasiswa program studi Pendidikan Akuntansi angkatan 2014 dan 2015 yang telah menempuh mata kuliah kewirausahaan. Angket tersebut terdiri dari 10 butir pernyataan. Data tersersebut kemudian diolah sehingga menghasilkan diperoleh skor tertinggi sebesar 40 dari 40, sedangkan skor terendahnya adalah 17 dari 10. Selain itu diketahui nilai Mean sebesar 28,31; Median sebesar 29; Modus sebesar 29; serta Standar deviasi sebesar 4,82.

Tabel 9. Distribusi Frekuensi Skor Variabel Teman Sebaya

\begin{tabular}{|l|l|c|l|}
\hline No & $\begin{array}{l}\text { Kelas } \\
\text { Interval }\end{array}$ & Frekuensi & Persentase \\
\hline 1 & $17-19$ & 6 & $5,26 \%$ \\
\hline 2 & $20-22$ & 22 & $19,30 \%$ \\
\hline 3 & $23-25$ & 14 & $12,29 \%$ \\
\hline 4 & $26-28$ & 28 & $24,56 \%$ \\
\hline 5 & $29-31$ & 38 & $33,33 \%$ \\
\hline 6 & $32-34$ & 8 & $7,02 \%$ \\
\hline 7 & $35-37$ & 5 & $4,39 \%$ \\
\hline 8 & $38-40$ & 7 & $6,15 \%$ \\
\hline & Jumlah & 114 & $100 \%$ \\
\hline
\end{tabular}

Berdasarkan tabel di atas dapat disimpulkan bahwa mayoritas skor jawaban responden terdapat pada kelas interval 29-31 sebanyak 38 responden $(33,33 \%)$, sedangkan frekuensi terkecil terdapat pada kelas interval 35-37 yang berjumlah 5 responden $(4,39 \%)$. 
Tabel 20. Distribusi Kecenderungan Variabel Teman Sebaya

\begin{tabular}{|l|l|l|l|}
\hline Kategori & $\begin{array}{l}\text { Interval } \\
\text { Skor }\end{array}$ & F & $\begin{array}{l}\text { Persen- } \\
\text { tase }\end{array}$ \\
\hline Mendukung & $\begin{array}{l}>30 \text { s.d } \\
40\end{array}$ & 31 & $27,19 \%$ \\
\hline $\begin{array}{l}\text { Cukup } \\
\text { Mendukung }\end{array}$ & $\begin{array}{l}>20 \text { s.d. } \\
30\end{array}$ & 76 & $66,67 \%$ \\
\hline $\begin{array}{l}\text { Kurang } \\
\text { Mendukung }\end{array}$ & $\begin{array}{l}10 \text { s.d. } \\
20\end{array}$ & 7 & $6,14 \%$ \\
\hline Jumlah & 114 & $100 \%$ \\
\hline
\end{tabular}

Tabel di atas menunjukkan bahwa sebanyak 31 responden $(27,19 \%)$ memiliki teman sebaya dengan kategori mendukung, 76 responden $(66,67 \%)$ memiliki teman sebaya yang cukup mendukung, dan sebanyak 7 responden $(6,14 \%)$ memiliki teman sebaya dengan kategori kurang mendukung. Penggolongan kategori dikatakan mendukung, cukup mendukung, dan kurang mendukung didasarkan pada indikator variabel Teman Sebaya yang digunakan. Semakin mahasiswa memiliki teman sebaya yang mendukung yaitu mencakup mengajarkan interaksi sosial, memberi pengetahuan, pengalaman, dan keterampilan, serta memberi dukungan positif dan kasih sayang maka dapat dikatakan teman sebaya mahasiswa semakin meningkatkan minat berwirausaha, begitu juga sebaliknya. Dari hasil itulah dapat ditarik kesimpulan bahwa penilaian responden terhadap variabel Teman Sebaya adalah cukup mendukung.

\section{Teman Sebaya}

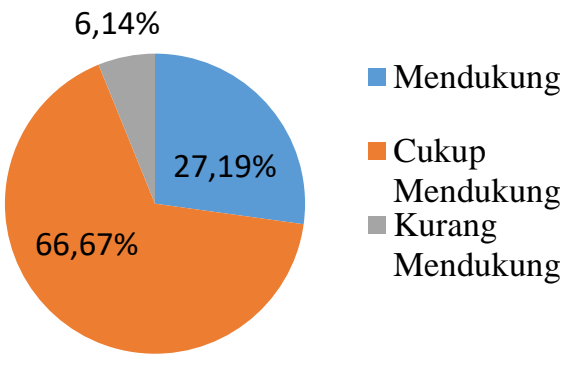

\section{Uji Prasyarat Analisis Data}

1. Uji Linieritas

Uji linieritas digunakan untuk mengetahui atau membuktikan apakah masing-masing variabel bebas (X) mempunyai hubungan yang linear atau tidak dengan variabel terikat (Y). Kriteria yang digunakan adalah jika pada taraf signifikansi $5 \%$ harga $F_{\text {hitung }} \leq$ $F_{\text {tabel }}$ maka bentuk regresi dikatakan linear, dan sebaliknya.

Tabel 11. Ringkasan Hasil Uji Linieritas

\begin{tabular}{|c|c|c|c|c|c|c|}
\hline \multirow{2}{*}{ No. } & \multicolumn{2}{|c|}{ Variabel } & \multirow{2}{*}{ F $_{\text {hitung }}$} & \multirow{2}{*}{ F $_{\text {tabel }}$} & $\begin{array}{c}\text { Nilai } \\
\text { Sig. }\end{array}$ & \multirow{2}{*}{ Ket. } \\
\cline { 2 - 3 } & $\mathbf{X}$ & $\mathbf{Y}$ & & 2,69 & 0,798 & Linier \\
\hline 1 & $\mathrm{X}_{1}$ & $\mathrm{Y}$ & 0,764 & 2,69 & Linier \\
\hline 2 & $\mathrm{X}_{2}$ & $\mathrm{Y}$ & 1,739 & 2,69 & 0,052 & Linier \\
\hline
\end{tabular}

Dari hasil tersebut maka terdapat hubungan yang linier antara variabel Kepribadian $\left(\mathrm{X}_{1}\right)$ dengan Minat Berwirausaha $(\mathrm{Y}), \quad$ variabel Lingkungan Keluarga $\left(\mathrm{X}_{2}\right)$ dengan Minat Berwirausaha (Y), dan variabel Teman Sebaya $\left(\mathrm{X}_{3}\right)$ dengan Minat Berwirausaha (Y).
2. Uji Multikolinieritas

Uji Multikolinearitas dilakukan untuk mengetahui apakah model regresi ditemukan adanya korelasi antar variabel bebas. Model regresi yang baik seharusnya tidak terjadi korelasi diantara variabel bebas (tidak terjadi Multikolinearitas). Ada tidaknya multikolinearitas dapat dilihat dari besarnya nilai tolerance 
dan variance inflation factor (VIF). Multikolinearitas terjadi bila pada kolom collinearity statistics menunjukkan nilai tolerance di bawah 0,10 dan VIF di atas 10 .

Tabel 32. Ringkasan Hasil Uji Multikolinearitas

\begin{tabular}{|c|c|c|c|}
\hline Variabel & TOL & VIF & Kesimpulan \\
\cline { 1 - 3 } X1 & 0,577 & 1,732 & \multirow{2}{*}{$\begin{array}{c}\text { Non- } \\
\text { Multikolinier }\end{array}$} \\
\cline { 1 - 2 } X2 & 0,586 & 1,707 & \\
\hline X3 & 0,837 & 1,195 & \\
\hline
\end{tabular}

Berdasarkan hasil uji multikolinearitas pada tabel di atas, menunjukkan bahwa semua variabel memiliki nilai tolerance $>0,10$ yaitu Kepribadian $0,577>0,10 ; \quad$ Lingkungan Keluarga 0,586>0,10; dan Teman Sebaya $0,837>0,10$. Selain itu semua variabel memiliki nilai $\mathrm{VIF}<10$ yaitu Kepribadian $1,732<10$; Lingkungan Keluarga 1,707<10; dan Teman Sebaya $1,195<10$. Berdasarkan angka tersebut berarti model regresi dalam penelitian ini tidak terjadi multikolinearitas.

3. Uji Heteroskedastisitas

Uji Heteroskedastisitas dilakukan dengan bantuan program aplikasi analisis statistik dan menggunakan Uji Glejser. Uji ini bertujuan untuk mengetahui apakah dalam model regresi terjadi ketidaksamaan varian dari residual satu pengamatan ke pengamatan yang lain. Kriteria pengambilan keputusan adalah jika nilai sig $>0,05$ maka tidak terjadi heteroskedastisitas.

Tabel 43. Ringkasan Hasil Uji Heteroskedastisitas

\begin{tabular}{|c|c|c|}
\hline Variabel & Sig. & Kesimpulan \\
\hline Kepribadian & 0,781 & \multirow{3}{*}{$\begin{array}{l}\text { Tidak terjadi } \\
\text { heteros- } \\
\text { kedastisitas }\end{array}$} \\
\hline $\begin{array}{l}\text { Lingkungan } \\
\text { Keluarga }\end{array}$ & 0,917 & \\
\hline $\begin{array}{l}\text { Teman } \\
\text { Sebaya }\end{array}$ & 0,386 & \\
\hline
\end{tabular}

Berdasarkan tabel di atas menunjukkan bahwa Kepribadian memiliki nilai sig sebesar 0781; Lingkungan Keluarga memiliki sig sebesar 0,917; dan Teman Sebaya memiliki nilai sig 0,386. Karena ketiga variabel memiliki nilai sig lebih besar dari 0,05 sehingga dapat disimpulkan bahwa penelitian ini tidak terjadi heteroskedastisitas.

\section{Uji Hipotesis Penelitian}

1. Uji Hipotesis Pertama

Hipotesis pertama dalam penelitian ini menyatakan bahwa terdapat pengaruh positif Kepribadian terhadap Minat Berwirausaha mahasiswa program studi Pendidikan Akuntansi Fakultas Ekonomi Universitas Negeri Yogyakarta.

Persamaan regresi yang diperoleh pada uji hipotesis pertama adalah sebagai berikut:

$$
\mathrm{Y}=0,595 \mathrm{X}_{1}+11,304
$$

Berdasakan persamaan tersebut dapat diketahui bahwa koefisien regresi sebesar 0,595 yang berarti jika nilai Kepribadian $\left(\mathrm{X}_{1}\right)$ ditambah satu satuan, maka akan diikuti peningkatan Minat Berwirausaha (Y) sebesar 0,595. Konstanta sebesar 11,304 berarti jika Kepribadian $\left(\mathrm{X}_{1}\right)$ sebesar 1, maka Minat Berwirausaha (Y) akan bertambah 11,304.

Hasil uji coba hipotesis pertama menunjukkan bahwa koefisien korelasi $\left(\mathrm{r}_{\mathrm{x} 1 \mathrm{y}}\right)$ sebesar 0,755 dengan koefisien determinasi $\left(\mathrm{r}^{2} \times 1 \mathrm{y}\right)$ 0,570 yang berarti variabel Minat Berwirausaha dipengaruhi oleh variabel Kepribadian sebesar 57\%, hal ini menunjukkan terdapat $43 \%$ faktor atau variabel lain yang kemungkinan berpengaruh terhadap Minat Berwirausaha. Hipotesis pertama yang menyatakan Kepribadian berpengaruh positif terhadap Minat Berwirausaha mahasiswa program studi Pendidikan 


\begin{abstract}
Akuntansi Fakultas Ekonomi Universitas Negeri Yogyakarta diterima karena koefisien Kepribadian bernilai positif dan memiliki $t_{\text {hitung }} 12,19>\mathrm{t}_{\text {tabel }}$ 1,981 serta nilai sig $0,000<0,05$.
\end{abstract}

\section{Uji Hipotesis Kedua}

Hipotesis kedua menyatakan bahwa terdapat pengaruh positif Lingkungan Keluarga terhadap Minat Berwirausaha mahasiswa program studi Pendidikan Akuntansi Fakultas Ekonomi Universitas Negeri Yogyakarta.

Persamaan regresi yang diperoleh pada uji hipotesis kedua adalah sebagai berikut:

$$
\mathrm{Y}=0,694 \mathrm{X}_{2}+17,867
$$

Berdasakan persamaan tersebut dapat diketahui bahwa koefisien regresi sebesar 0,694 yang berarti jika nilai Lingkungan Keluarga $\left(\mathrm{X}_{2}\right)$ ditambah satu satuan, maka akan diikuti peningkatan Minat Berwirausaha (Y) sebesar 0,694. Konstanta sebesar 17,867 berarti jika Lingkungan Keluarga $\left(\mathrm{X}_{2}\right)$ sebesar 1, maka Minat Beriwrausaha (Y) akan bertambah 17,867 .

Hasil uji hipotesis kedua menunjukkan bahwa koefisien korelasi $\left(\mathrm{r}_{\mathrm{x} 2 \mathrm{y}}\right)$ sebesar 0,515 dengan koefisien determinasi $\left(r^{2}{ }^{2} y\right)$ 0,265 yang berarti variabel Minat Berwirausaha dipengaruhi oleh variabel Lingkungan Keluarga sebesar 26,5\%, hal ini menunjukkan terdapat $73,5 \%$ faktor atau variabel lain yang kemungkinan berpengaruh terhadap Minat Berwirausaha. Hipotesis kedua yang menyatakan Lingkungan Keluarga berpengaruh positif terhadap Minat Berwirausaha mahasiswa program studi Pendidikan Akuntansi Fakultas Ekonomi Universitas Negeri Yogyakarta diterima karena koefisien Lingkungan Keluarga bernilai positif dan memiliki thitung $6,358>\mathrm{t}_{\text {tabel }} 1,981$ serta nilai sig $0,000<0,05$.
3. Uji Hipotesis Ketiga

Hipotesis ketiga menyatakan bahwa terdapat pengaruh positif Teman Sebaya terhadap Minat Berwirausaha mahasiswa program studi Pendidikan Akuntansi Fakultas Ekonomi Universitas Negeri Yogyakarta.

Persamaan regresi yang diperoleh pada uji hipotesis ketiga adalah sebagai berikut:

$$
\mathrm{Y}=0,537 \mathrm{X}_{3}+21,916
$$

Berdasakan persamaan tersebut dapat diketahui bahwa koefisien regresi sebesar 0,537 yang berarti jika nilai Teman Sebaya $\left(X_{3}\right)$ ditambah satu satuan, maka akan diikuti peningkatan Minat Berwirausaha (Y) sebesar 0,537. Konstanta sebesar 21,916 berarti jika Teman Sebaya $\left(\mathrm{X}_{3}\right)$ sebesar 1, maka Minat Beriwrausaha (Y) akan bertambah 21,916.

Hasil uji hipotesis tiga menunjukkan bahwa koefisien korelasi $\left(\mathrm{r}_{\mathrm{x} 2 \mathrm{y}}\right)$ sebesar 0,453 dengan koefisien determinasi $\left(r^{2}{ }_{x 1 y}\right) 0,205$ yang berarti variabel Minat Berwirausaha dipengaruhi oleh variabel Teman Sebaya sebesar 20,5\%, hal ini menunjukkan terdapat $79,5 \%$ faktor atau variabel lain yang kemungkinan berpengaruh terhadap Minat Berwirausaha. Hipotesis ketiga yang menyatakan Teman Sebaya berpengaruh positif terhadap Minat Berwirausaha mahasiswa program studi Pendidikan Akuntansi Fakultas Ekonomi Universitas Negeri Yogyakarta diterima karena koefisien Teman Sebaya bernilai positif dan memiliki $t_{\text {hitung }} 5,372>\mathrm{t}_{\text {tabel }} 1,981$ serta nilai sig $0,000<0,05$.

4. Uji Hipotesis Keempat Hipotesis keempat menyatakan bahwa terdapat pengaruh positif Kepribadian, Lingkungan Keluarga, dan Teman Sebaya secara bersama-sama terhadap 
Minat Berwirausaha mahasiswa program studi Pendidikan Akuntansi Fakultas Ekonomi Universitas Negeri Yogyakarta.

Persamaan regresi yang diperoleh dari hasil uji hipotesis keempat adalah sebagai berikut:

$Y=0,525 X_{1}+0,035 X_{2}+0,231 X_{3}+6,832$

Persamaan tersebut menunjukkan bahwa koefisien $X_{1}$ sebesar 0,525 memiliki arti jika nilai Kepribadian $\left(\mathrm{X}_{1}\right)$ ditambah satu satuan dan nilai Lingkungan Keluarga $\left(\mathrm{X}_{2}\right)$ serta Teman Sebaya $\left(X_{3}\right)$ adalah 1 , maka nilai Minat Berwirausaha (Y) akan meningkat sebesar 0,525. Koefisien $\mathrm{X}_{2}$ sebesar 0,035 memiliki arti jika nilai Lingkungan Keluarga $\left(\mathrm{X}_{2}\right)$ ditambah satu satuan dan nilai Kepribadian $\left(\mathrm{X}_{1}\right)$ serta Teman Sebaya $\left(X_{3}\right)$ adalah 1 , maka nilai Minat Berwirausaha (Y) akan meningkat sebesar 0,035. Koefisien $\mathrm{X}_{3}$ sebesar 0,231 memiliki arti jika nilai Teman Sebaya $\left(\mathrm{X}_{3}\right)$ ditambah satu satuan dan nilai Kepribadian $\left(\mathrm{X}_{1}\right)$ serta Lingkungan Keluarga $\left(\mathrm{X}_{2}\right)$ adalah 1, maka nilai Minat Berwirausaha (Y) akan meningkat sebesar 0,231. Konstanta sebesar 6,832 berarti jika Kepribadian $\left(\mathrm{X}_{1}\right)$, Lingkungan Keluarga $\left(\mathrm{X}_{2}\right)$, dan Teman Sebaya $\left(\mathrm{X}_{3}\right)$ sebesar 1 , maka Minat Berwirausaha (Y) akan bertambah 6,832 .

Hasil uji hipotesis keempat menunjukkan bahwa harga koefisien korelasi $\left(\mathrm{R}_{\mathrm{y}(1,2,3)}\right)$ sebesar 0,778 yang berarti besarnya pengaruh Kepribadian, Lingkungan Keluarga, dan Teman Sebaya secara bersamasama terhadap Minat Berwirausaha adalah sebesar 0,778. Harga koefisien determinasi $\left(\mathrm{R}_{\mathrm{y}(1,2,3))}^{2}\right.$ sebesar 0,605 memiliki arti $60,5 \%$ Minat Berwirausaha dipengaruhi oleh Kepribadian, Lingkungan Keluarga, dan Teman Sebaya secara bersama- sama, selebihnya sebesar 39,5\% dipengaruhi oleh faktor atau variabel lain yang tidak diteliti dalam penelitian ini. Berdasarkan tabel 22, dapat diketahui bahwa nilai $\mathrm{F}$ adalah 56,068 dengan sig 0,000 karena sig $0,000<0,05$ maka $\mathrm{H}_{0}$ ditolak. Jadi dapat disimpulkan bahwa pada taraf signifikansi 0,05 terdapat pengaruh yang positif Kepribadian, Lingkungan Keluarga, dan Teman Sebaya secara bersama-sama terhadap Minat Berwirausaha mahasiswa program studi Pendidikan Akuntansi Fakultas Ekonomi Universitas Negeri Yogyakarta.

Berdasarkan hasil analisis regresi ganda dapat dihitung besarnya Sumbangan Relatif dan Sumbangan Efektif masing-masing variabel bebas terhadap variabel terikat yaitu Kepribadian, Lingkungan Keluarga, dan Teman Sebaya terhadap Minat Berwirausaha. Besarnya sumbangan relative dan sumbangan efektif dapat dilihat pada tabel berikut:

Tabel 5. Ringkasan Hasil Perhitungan
Sumbangan Relatif dan
\begin{tabular}{|c|l|c|c|} 
Sumbangan Efektif \\
\hline \multirow{2}{*}{ No. } & Variabel & \multicolumn{2}{|c|}{ Sumbangan } \\
\cline { 3 - 4 } & Relatif & Efektif \\
\hline 1 & Kepribadian & $75,35 \%$ & $45,59 \%$ \\
\hline 2 & $\begin{array}{l}\text { Lingkungan } \\
\text { Keluarga }\end{array}$ & $3,19 \%$ & $1,93 \%$ \\
\hline 3 & $\begin{array}{l}\text { Teman } \\
\text { Sebaya }\end{array}$ & $21,46 \%$ & $12,98 \%$ \\
\hline & Total & $100 \%$ & $60,5 \%$ \\
\hline
\end{tabular}

Berdasarkan tabel di atas dapat diketahui bahwa variabel Kepribadian memberikan Sumbangan Relatif sebesar 75,35\%; variabel Lingkungan Keluarga memberikan Sumbangan Relatif sebesar 3,19\%; dan variabel Teman Sebaya memberi Sumbangan Relatif sebesar 21,46\%. Sedangkan Sumbangan Efektif dari variabel Kepribadian sebesar $45,59 \%$; variabel 
Lingkungan Keluarga sebesar 1,93\%; dan variabel Teman Sebaya sebesar $12,98 \%$ sehingga total Sumbangan Efektif adalah sebesar $60,5 \%$ yang berarti variabel Kepribadian, Lingkungan Keluarga, dan Teman Sebaya secara bersama-sama memberikan Sumbangan Efektif sebesar $60,5 \%$ dan sisanya yaitu $39,5 \%$ dipengaruhi oleh variabelvariabel lain yang tidak dibahas dalam penelitian ini.

\section{SIMPULAN DAN SARAN \\ Simpulan}

a. Terdapat pengaruh positif Kepribadian terhadap Minat Berwirausaha Mahasiswa Program Studi Pendidikan Akuntansi Fakultas Ekonomi Universitas Negeri Yogyakarta. Hal ini ditunjukkan dengan nilai $r_{x 1 y}$ sebesar 0,$755 ; r_{x 1 y}^{2}$ sebesar 0,570 dan persamaan regresinya adalah $\mathrm{Y}$ $=0,595 \mathrm{X}_{1}+11,304$.

b. Terdapat pengaruh positif Lingkungan Keluarga terhadap Minat Berwirausaha Mahasiswa Program Studi Pendidikan Akuntansi Fakultas Ekonomi Universitas Negeri Yogyakarta. Hal ini ditunjukkan dengan nilai $r_{x 2 y}$ sebesar 0,$515 ; r_{x 2 y}^{2}$ sebesar 0,265 dan persamaan regresinya adalah $\mathrm{Y}=0,694 \mathrm{X}_{2}+17,867$

c. Terdapat pengaruh positif Teman Sebaya terhadap Minat Berwirausaha Mahasiswa Program Studi Pendidikan Akuntansi Fakultas Ekonomi Universitas Negeri Yogyakarta. Hal ini ditunjukkan dengan nilai $r_{x 3 y}$ sebesar 0,$453 ; r_{x 3 y}^{2}$ sebesar 0,205 dan persamaan regresinya adalah $Y$ $=0,537 \mathrm{X}_{3}+21,916$.

d. Terdapat pengaruh positif Kepribadian, Lingkungan Keluarga, dan Teman Sebaya secara bersama-sama terhadap Minat Berwirausaha Mahasiswa Program Studi Pendidikan Akuntansi Fakultas Ekonomi Universitas Negeri Yogyakarta. Hal ini ditunjukkan dengan nilai $\mathrm{R}_{\mathrm{y}}$ sebesar 0,778; $\mathrm{R}_{\mathrm{y}}^{2}$ sebesar 0,605 dan persamaan regresinya adalah $\mathrm{Y}=$ $0,525 X_{1}+0,035 X_{2}+0,231 X_{3}+6,832$.

\section{Saran}

a. Bagi Mahasiswa Program Studi Pendidikan Akuntansi

Berdasarkan data hasil penelitian, skor terendah pada variabel Minat Berwirausaha terdapat pada pernyataan "Saya tertarik berwirausaha sehingga setelah lulus kuliah saya tidak mencari pekerjaan melainkan menciptakan lapangan kerja (berwirausaha)." Artinya adalah setelah lulus dari perguruan tinggi mahasiswa cenderung lebih memilih untuk mencari pekerjaan selain menjadi wirausaha. Berdasarkan hasil wawancara pada sebagian besar mahasiswa juga menghasilkan informasi bahwa mahasiswa lebih memilih untuk bekerja nantinya setelah lulus dari perguruan tinggi. Sebaiknya mahasiswa sebagai penerus bangsa lebih berorientasi untuk menciptakan lapangan pekerjaan agar dapat membantu mengurangi beban pemerintah dalam mengatasi permasalahan pengangguran, tidak hanya sibuk mencari pekerjaan/memasukkan lamaran kerja yang mengindikasikan ketergantungan pada orang lain. Selain itu skor terendah juga ada pada variabel Kepribadian terdapat pada pernyataan "Sifat mudah bosan yang saya memiliki membuat usaha saya tidak akan berjalan lama." Hal tersebut memiliki arti bahwa mahasiswa tidak dapat mengendalikan rasa bosan yang dimiliki untuk fokus pada suatu hal yang harus dipertahankan. Sebaiknya mahasiswa belajar mengendalikan rasa bosan yang sering kali melanda dengan tidak boleh menyerah dan putus asa untuk mempertahankan usahanya, akan lebih baik jika meningkatkan kreativitas dan inisiatif untuk mengembangkan usahanya agar ketika rasa bosan itu datang dapat teratasi dengan suatu hal yang baru.

b. Bagi Keluarga dan Teman Mahasiswa 
Berdasarkan data hasil penelitian, skor terendah pada variabel Lingkungan Keluarga terdapat pada pernyataan "Kakak adik saya memberi masukan agar usaha saya dapat lebih maju dan berkembang." Artinya adalah keluarga kurang mendukung minat mahasiswa untuk berwirausaha karena kurangnya masukan, saran, kritikan, maupun perhatian. Sebaiknya keluarga yang merupakan lingkungan utama bagi mahasiswa dapat memberi dukungan terhadap minat berwirausaha dengan memberikan perhatian, masukan yang positif, saran dan kritik yang membangun, serta semangat dan dorongan dari keluarga akan berdampak baik bagi tumbuhnya minat berwirausaha mahasiswa. Selain itu data hasil penelitian juga menunjukan skor terendah pada variabel Teman Sebaya terdapat pada pernyataan "Saya dan teman sebaya membuka stand produk disuatu tempat." Hal ini bermakna bahwa dukungan fisik (act) dari teman sebaya masih rendah terhadap minat mahasiswa berwirausaha. Sebaiknya mahasiswa lebih meningkatkan intensitas komunikasi dan action terlebih pada minat yang sama. Saling terbuka untuk bertukar pikiran cukup penting guna mendapatkan dukungan fisik maupun non fisik dari lingkungan sekitar seperti teman dan keluarga.

c. Bagi Instansi/Universitas

Perlu adanya peningkatan bagi pihak universitas dalam memberikan pemahaman dan pelatihan kewirausahaan agar bertambahnya minat dan kemampuan mahasiswa dalam berwirausaha sehingga lulus dari perguruan tinggi sudah cukup keyakinan, ilmu yang dikuasi, dan kemampuan yang didapatkan untuk selanjutnya dipraktikkan dengan berwirausaha atau menciptakan lapangan pekerjaan. Selain itu perlu adanya penggencaran informasi untuk mendorong mahasiswa agar dapat memanfaatkan fasilitas laboratorium kewirausahaan yang ada, atau dengan mendorong program-program dari organisasi mahasiswa khususnya bidang kewirausahaan sebagai sarana belajar terjun langsung dalam dunia wirausaha.

d. Bagi Peneliti Selanjutnya

Penelitian ini memberikan informasi bahwa faktor Kepribadian, Lingkungan Keluarga, dan Teman Sebaya memiliki pengaruh positif terhadap Minat Berwirausaha mahasiswa program studi Pendidikan Akuntansi Fakultas Ekonomi Universitas Negeri Yogyakarta. Diharapkan penelitian selanjutnya dapat mengungkap faktor lain yang memengaruhi Minat Berwirausaha selain ketiga faktor yang telah diteliti dalam penelitian ini. Instrumen bentuk kuesioner yang dirancang dalam penelitian ini masih belum dirancang dengan baik, karena masih terdapat double barreled question yaitu satu pertanyaan yang berisi dua issue. Diharapkan penelitian selanjutnya dapat merancang kuesioner/instrumen dengan sebaik mungkin agar terhindar dari double barreled question yang dapat membingungkan responden untuk mengisi kuesioner.

\section{DAFTAR PUSTAKA}

Alma, Buchari. (2013). Kewirausahaan. Bandung: Alfabeta.

\section{Ariyanti, Fiki. (2018). Jumlah Wirausaha RI Siap Kejar Malaysia. Bisnis.liputan6.com diakses tanggal 15 Januari 2018.}

Badan Pusat Statistik. (2018). "Penduduk Berumur 15 Tahun Ke Atas Menurut Jenis Kegiatan Tahun 1986-2017". Diakses dari www.bps.go.id pada 15 Januari 2018.

"Pengangguran Terbuka Menurut 
Pendidikan Tertinggi yang Ditamatkan Tahun 1986-2017". Diakses dari www.bps.go.id pada 15 Januari 2018.

Chandra, Surya. (2017). "Demografi Indonesia 2045". Diakses dari keluargaindonesia.id pada 10 Oktober 2017.

Daryanto, dkk. (2013). Kewirausahaan: Penanaman Jiwa Kewirausahaan. Yogyakarta: Gava Media.

Hasbullah. (2009). Dasar-Dasar Ilmu Pendidikan. Jakarta: PT Rajagrafindo Persada.

Heflin Frinces. (2010). Pentingnya Profesi Wirausaha Di Indonesia. Jurnal Magister. Yogyakarta: STIE Mitra Indonesia Yogyakarta.

Kasmir. (2011). Kewirausahaan. Jakarta: PT RajaGrafindo Persada.

Liputan6. (2017). “Top 3: 10 Besar Instansi Favorit Pelamar CPNS 2017”. Diakses dari m.liputan6.com pada 10 Oktober 2017.

Sarwono, Sarlito. (2012). Pengantar Psikologi Umum. Jakarta: PT RajaGrafindo Persada.

Wagiran. (2013). Metodologi Penelitian Pendidikan: Teori dan Implementasi. Yogyakarta: Deepublish.

Wang, Clement. (2004). Entrepreneurial interest of university students in Singapore. Jurnal. Singapore: National University of Singapore. 